\title{
Active Methodologies as Strategies of Interactive Teaching Learning: An Experiment with Problem Based Learning (PBL)
}

\author{
${ }^{1}$ Ana Maria de C. Leite, ${ }^{2}$ Lídia Maria N. Alves, ${ }^{3}$ Humberto V. Altino Filho \\ ${ }^{1} U F M G$ \\ ${ }^{2} U E M G-M G ; F A C I G$ \\ ${ }^{3} U F O P$
}

\begin{abstract}
The demands of the modern and globalized world have called on teachers to educate for autonomy, leadership and cooperation. New methods come every time to meet the educational call the historical moment in which we live. In this way, we intended to highlight the active learning methodologies that have been used for this purpose, since, in essence, they bring the so-called student's role, which is to take students to the center of the learning process. In order to test the effectiveness of the methodologies in question, we chose Problem Based Learning (PBL) as experimentation with undergraduate students and elementary school students. The results of which were satisfactory in what refers to the expected results: students and teacher interaction, as well as development of criticality. This work was developed from the research project "Poetics of modernity: a look at difference", developed by professor Lidia Maria Nazaré Alves, coordinated by professor Alexandre H. C. Bittencourt, financed by PAPq / UEM. The success of this experience was the motivating factor for our participation in the International Conference on Education (iice-2016), with the workshop "The Active Methodologies as Optimizers of Teaching / Learning Formation of Critical Citizens".
\end{abstract}

\section{Introduction}

The education unrelated to reality, allowing its students to live a life constructed by others, transforming them into alienated subjects, has been at the center of the discussions of different social segments. Therefore, the observation about the need to associate school and life is not new in our midst. Good literature always precedes social questions, and the writer of Brazilian Realism, Pompeia [1], already presumed this in the nineteenth century. In the first line of his masterpiece, "The Athenaeum", the narrator, now an adult recalls a speech from his father when he took him to boarding school: "You will find the world, my son. Courage to fight" [1]. Since then, it was already anticipated, by the aforementioned, the need to educate in life and for life.
The word "struggle" suggests that education should promote the construction of a subject prepared to face, but also not only, to dialogue and negotiate with the diversity proper to any historical period. Despite all this call for the necessity of such a relation, education in Brazil, but not only, was always based on the transmission of a positivist knowledge - we call this type of education in Brazil as "traditional education" -, very dissociated with the reality of the student. The instruments of data collection, such as questionnaires, arguments, evaluations, and evidence were no more than a measurer that had previously been transmitted. What put this discourse in check were the textual productions, called "compositions" in this context, we were always very adventurous and writing accompanied the coming and going of thought - and experiences in science classes - we observed the germination of different types of grains, and watched them grow. The productivity of this traditional model can contribute to a follow-up of life: submission to government tests, done throughout Elementary School, high school and the graduation, but it does not really help the student to deal with life.

The reasons for this problem are the dissociability between standardized school education and the Brazilian reality, so marked by diversity. This paradox has been observed for a long time. In 1922, at the height of the Modern Art Week in Brazil, Mário de Andrade, one of its main idealizers, took up the historical event known to all of the catechization of the Indigenous and, on the same occasion, played with contemporaries and postal workers writing: We were never catechized. We did it was carnival. The Indigenous dressed as senator of the empire (...) or appearing in the operas of Alencar full of good Portuguese feelings (...)" [2]. These verses show a time when Brazilian cultural diversity, resulting from the mixture of Brazilian, European and African autochthonous, was not even alluded to within school walls.

To encompass this diversity, it is necessary for the education model to extrapolate the predetermined patterns and to contemplate the different needs and capacities presented by the students. 


\section{Theoretical talk: The Reflection on Pedagogical Practice}

The reflections on the need to rethink our pedagogical practice come from the observation of the diagnosis of the existing reality added to the observation of the difficulties of the students in course of at least two Institutions where we have been teaching for several years. They are a public elementary and middle school, in the interior of state Minas Gerais (Brazil), and the State University of Minas Gerais (UEMG -Carangola Unit), where the researchers work.

With regard to elementary and middle school, the problem lies in the observance that, after the third year, few were enrolled in Higher Education. Most of them could not score satisfactory to attend a graduation that seems more significant. We also realized that students are oblivious to the problems of the world, limiting themselves to the end of the course, getting sub-jobs with few prospects for a promising future.

In the undergraduate courses, the problem resides around the construction of diverse strategies and necessary inferences, required for those who will teach classes, because they are constant in the school routine. It is seen that methodologies that point to the real needs of the learner student, future teacher, is unsatisfactory.

This dichotomy theory / practice of everyday life begins from the first contacts of the student with the school, because it has been erected under the aegis of positivism since the first moments of the Republic and still drags the rancid of such a paradigm.

From 1859, in the formation of the Republic, the positivist ideas of Augusto Comte began to spread, mainly in Rio de Janeiro, in academic and intellectual circles. They reached the army, mainly through the preaching of Benjamin Constant, which affirmed that the Army should have a prominent role in the direction of the State, guaranteeing the order, indispensable to the capitalist progress.

The result of this authoritarianism, recalls José Murilo de Carvalho [3] was that the people did not speak for themselves; had no voice of their own, their identity and the identity of the nation were granted by the military regime. If 1937 seems a distant year, we can rethink it if we turn our gaze to 1964, the time of the military Dictatorship that extended for a long period. The fact is that whatever had been the causes of repression - the formation of national identity, the building of an image of the nation - they silenced the voice of the people and intimidated their actions. The reflexes of this are found in the educational model of Brazil, very marked, as we have said, by the positivist paradigm that prioritizes the transmission of school content and the application of techniques with the purpose of guaranteeing the teaching of these contents, to the detriment of dialogism and Binomial equation school theory and everyday practice.

Many governmental documents point to the school as an instrument for the formation of critical thinking. Thus, the institutions that form these teachers multiplying such consciences should receive an education that enables them to do so. From the new LDB there must be a link between theory and practice in the formation of the teacher's identity as an educator. A conception of practice more as a curricular component implies seeing it as a dimension of knowledge, which is present both in the training courses at the moments when one works on reflection on the professional activity, and during the stage in the moments in which the professional activity [4].

In this perspective, the practice is closely linked to the much-needed research process in the literature course. His dissociation with theory, recalls Sacristán and Gómez [5].

It distorts the educational nature of research, since it prevents or hinders the enriching link between knowledge and action, to develop an informed and reflexive action at the same time as an educational knowledge, committed to value options and refined in the tensions and resistances of practice.

The need for change is urgent. Therefore, we meet in a timely manner to discuss possible strategies to reflect on the problem. We are certain, however, of the difficulties that exist because we teachers of Elementary and Middle School as well as the Course of Letters are products of a traditional educational system and, therefore, we are not free to reiterate it in our pedagogical practices. Thus, in the first instance, a long reflection on the rescue of the role of the teacher as subject of transformation is required. For this reason, some questions are fundamental: Does my pedagogical practice reiterate the positivist paradigm? $2^{\mathrm{a}}$. If it is yes or no, why?

To answer these questions, we did a survey of the authors who are most cited as theoretical references for teacher training and found support in teacher Donald A. Shön [6]. Shön [6] proposes to the professional the notion of reflective practice that is, to reflect on the action itself, equating the binomial, until then fragmented theory and practice. Although his study is not focused on teacher training, it facilitates the understanding of "how" we can work more productively the training of our students. The teacher will explain the following keywords: knowledge in action, reflection in action, reflection on reflection in action.

In this way, we intend that the discussions about the Pedagogical Practice serve as a guiding and instrument axis so that the teachers can understand the teaching experience as an important contribution in the formation of reflective teachers. The initial diagnosis showed that the possible fields of work of our elementary and middle school students and graduation are marked by heterogeneity. In addition, 
they also constitute a heterogeneous group. As we know, there are no recipes for working with groups of this nature, so we have to create - to work with them and help them to create - to live in their daily lives and work with their students - strategies to act efficiently and safe. It seems that the educational and social complexity of the modern world is one of the driving forces that lead us to reflect on new ways of structuring our pedagogical practice. Sacristán and Gómez [5] take into account the fact that they oppose the "linear" and "mechanical" process of the socialization process in school. For them the process must be complex and subtle marked by deep contradictions, inevitable individual, and group resistance, after all this is the context outside the walls of the school.

From the authors mentioned above we see that a homogeneous school in its structure, in its way of thinking, traditionally guided by a program, makes it impossible to develop ideas, attitudes, and differentiated strategies that meet the demands of the labor market. Moreover, it is precisely the knowledge and use of the strategies, the change of them when necessary, that will give security to the professional, as already mentioned above.

Morin [7] states that "strategy" is defined as "opposition" to the program. A program is a sequence of predetermined actions that can only be performed in an environment with "few" eventualities or disorders. The program is effective under "stable" external conditions, which can be safely determined. However, the slightest disturbance in these conditions deregulates the execution of the program and forces it to stop. Strategy, like the program, is established for an objective; will determine the developments of the action and choose one based on what it knows about an "uncertain" environment. "The strategy seeks ceaselessly to gather the information collected and the accidents encountered during the course" [7].

Although the guidelines to be met (established in pedagogical planning) are present in the daily life of teachers, most of the pedagogical practices developed are based on the knowledge produced in these same practices, since "the strategy can modify the script of actions predicted, in the light of the new information that comes along the path she can invent "[7].

For this reason, the study and investigation procedures will be of such a nature as to be able to inquire into the production and exchange of meanings, whatever means or transmission vehicles are used. The external and observable indicators of the events in the class will not be susceptible to addition and subtraction. The procedures used will enable the understanding of the meaning of such indicators, placing them in the physical, psychosocial and pedagogical context that conditions them.

Knowledge in action is the knowledge that the professionals demonstrate in the execution of the action; is tacit and manifests itself in the spontaneity with which an action is well performed. Such knowledge is what Chalier [8] understands by routines - another conception of Schön for the professional - that would constitute the very essence of the professional's action. Action schemes and routines would be automatically activated in response to middle indicators and articulated with each other to enable the practitioner to be effective in the immediate. It is a dynamic knowledge. However, sometimes the situation is more complex and requires a verbal description by the teacher of what he is doing. In this case, he should reflect on the action and adapt it by experimenting with new behaviors. The reflection in action is the verbal description that occurs simultaneously with the action, without interruption, although with brief moments of detachment.

Faced with two distinct theoretical positions and the student's expectation of which of them is most feasible, the teacher will mobilize this scheme of action, reflect during the action, initiate a conversation with one's own situation. This does not mean that he will find an objective response - although he can do so - but that at the very least will promote intellectual debate by making the group safer. At the same time, the teacher will keep in mind certain schemes that can be used in due course.

Often reflection occurs at a later stage of practice; in this case, we have the verbal description understood by Schön [6] as a reflection on the action. This scheme of action will be constant in the course of Letters because we will be discussing in the classroom about how a certain situation was or could have been approached in a more productive and / or formative way for the students. As in the previous case, here too the teacher can use the schemes that he keeps in his memory whenever necessary.

Reflection on reflection in action is the process that leads the teacher to progress in his development and build his personal form of knowledge. Reflection on reflection in action helps us to determine our future actions, to understand futures, or to discover new solutions.

The adoption of this practice allowed us to perceive the need to place the students at the center of the process of the teaching-learning relationship, making them the protagonist. This finding certainly points to new methodological paradigms, as we expose in the next section.

\section{The choice of active methodologies}

From the reflections on pedagogical practice in force, we highlight the importance of bringing education research closer to the two realities that concern it: the university and the basic education school. Therefore, we have researched new methodologies that can overcome the distance between school education and reality, and promote 
thinking about the construction of a critical subject, protagonist of his own knowledge. As an example of this initiative, Faculty of Management Sciences of Manhuaçu (FACIG) has been working with the insertion of active methodologies since 2012. The principal organized a book with guidelines on the application of some of these methodologies. After selecting the methodologies, the principal instructed three teachers to study and share them with others. The purpose of the meetings was to practice formatting - group work - and experimentation of activities, as would occur within the classroom and other similar places.

The insertion occurred gradually, so as not to frighten the students and the teachers, accustomed to the transmission of knowledge. Initially $50 \%$ of the classes would be taught using the active methodologies, later 75\% and today, 2017, almost all courses of the FACIG Institution have their classes taught with $100 \%$ of active methodologies. According to Hannas [9]: all the evaluations carried out so far on the influence of the application of active methodologies on the learning and performance of the students of the institution was positive" [9].

Talking about the crossing of a traditional methodology to an active methodology is an easy and healthy task, but the process in focus was challenging. In order to opt for such crossing, it is necessary to have vision, daring, confidence and risks. Vision to see the results that will follow, daring to start a business that may not work, trust by believing in the group - diversified - executor of the task and risks of being located in a small city, whose methodologies used in neighboring colleges, still find In the transmission of knowledge.

In the early years of the application of active methodologies, it was commonplace at College for teachers to feel uncomfortable within the classroom for two main reasons: for the change of place and social function that had been relegated to them by tradition. His place became the whole space of the classroom and beyond. Its function became the one of fomenter and of mediator of systematized knowledge, but not only, in potential, in each student.

With regard to students, it is productive to remember their suspicions about the new social function of the teacher and the effectiveness of the method. It was not uncommon for students to claim that the teacher was not giving class. Many teachers felt offended, but the fact is that their function really was no longer to give lessons, but to enable the event lesson. The allegations no longer occur because the use of methodologies is integrated. It could be said that everyone speaks a single language in the institution.

Gradually the education given at FACIG was acquiring a new format and new philosophy. It might be said that an ancient idea of Plato, concerning the condition indispensable to all teaching, was at its threshold: "Eros, which is, at the same time, desire, pleasure and love; Desire and pleasure to convey, love of knowledge and love for students [10]. FACIG team, demanding as life, announced to us a new format to make education happen. Moreover, we believe in him. Anyone who crossed his arches would be on the verge of meeting life, as Pompeia had said before.

\section{The description of active methods}

The systematization of active methodologies as it is known today dates from the 1960s, in Canada, initially applied in medical school, now being used in several areas of knowledge. Among the various active methods, we can mention Problem-Based Learning (PBL), student-centered, that uses real problems or simulated, aiming to encourage him to solve this problem from their positive attitudes, critical thinking and skills.

The Peer Instruction, a method which provides for the preliminary study of certain content, and in the classroom, questions are presented to students, who resolved, first, individually, and if the percentage of arrangements are not satisfactory, the students are encouraged to discuss with colleagues in peers.

Team Based Learning (TBL) that provides a preliminary study of a certain topic and / or content that in the classroom will be discussed form of individual questions answered and then in teams.

Flipped Classroom that we can use the technological resources in mediation of this method to streamline in student, the possibilities of seeking content videos, in hypertext, groups on social networks, virtual libraries, interviews with experts on the content etc., and, of course, the student power advance measure his level of ownership of the previous content with the help of technological resources measurement.

Although each method has its importance, in this article we focus on the PBL, because it was considered more adequate to work with the research participants. This method presents seven important steps: 1. Reading the problem, identifying and clarifying terms unknown; 2. Identification of the problems proposed by the statement; 3 . Formulation of explanatory hypotheses for problems identified in the previous step (students are using at this stage of their knowledge of the subject); 4. Summary of hypotheses; 5. Formulation of learning objectives (This is the identification of what the student should study for deepen the incomplete knowledge explanatory hypotheses); 6. Individual study of subjects learning objectives; 7. Return to the group tutorial to re-discuss the problem with the new knowledge acquired during the previous study phase.

Next, we describe how the researchers have adapted and applied this method in the development of the research. 


\section{Research on the Application of Active Methods - Procedures}

In order to carry out the research, we have used bibliographic consultation, as we deem it productive to clarify the need to rethink our pedagogical practice. By bibliographic consultation, about the insertion of the active methodologies in the FACIG, where the researchers encountered the method, given them role as teachers, in the aforementioned. Along with the theoretical basis, we seek to reconcile the steps of action research, since it can overcome the gaps between educational research and teaching practice. That is, between theory and practice, and the results increase teachers' comprehension skills and their therefore greatly favor changes. According to Elliott [11], action research is a process that continually changes in spirals of reflection and action, where each spiral includes:

- Clarify and diagnose a practical situation or a practical problem that one wants to improve or solve.

- Formulate strategies for action.

- Develop these strategies and evaluate their effectiveness.

- Expand understanding of the new situation.

- Proceed to the same steps for the new practical situation.

Observing these methodological issues, we conducted a research on the application of PBL in two schooling levels: undergraduate and basic education. To the $\mathrm{PhD}$ professor, we will call researcher I. To the undergraduate student, we call researcher II.

\subsection{Development of research in University}

At the University, the researcher I applied the PBL in a Letter class. In that time, they had launched the announcement of the fourth UEMG Week, which would take place from September 11 to 19, 2015, whose theme was "Diversity and Afrodescendence". The Brazilian Law 10.639 makes it compulsory to teach African history in schools since the early years. Aiming at the valorization of this, the researcher 1 chose two texts by the Brazilian writer Monteiro Lobato, both of them thematically speaking Afrodescendence. The choice was justified because, according to some militant groups, the writer treats the disrespectful blacks, from the treatment given to one of its personages, Aunt Nastácia. For this accusation, of racist nature, the militant group asks for the withdrawal of two of its works of circulation. The question is quite serious because the aforementioned is considered by literary critic as the father of
Brazilian children's literature, being, the books in question, destined, mainly, to that group. The researcher I suggested the reading of the books on screen and, after that, she published the follow text on the subject.

\section{Text 01}

João Luís Ceccantini researcher on children's literature and co-author of the book Monteiro Lobato - Book a Book, states: "Wanting to censor or modify to some degree a cultural work is absurd."

A student of the assimilation of literature by children, Ceccantini adds information to the debate about Lobato that demolishes finally the arguments of the censors, who claim that Lobato's works hinder the formation of children. "I have studied how children absorb what they read and my conclusion is that they know how to identify the excesses of books. They cling to what is good, to the essence of the stories and, in Lobato's case, this essence is not racist. ", Continues Veja Magazine says: Lobato Letters recently revealed show the author's sympathy for theses of eugenics (Current that defended the improvement of the species through genetic selection and reproduction control). Should this have permeated the analysis of the author's work?

Ceccantini replies: Lobato was, above all, a humanist. He fought for equality, for democracy, and there is not a single episode that links corruption in any sphere. In addition, he suffered a lot for it. Disappointed with the directions the country was taking at that time, he was a staunch critic of Brazil. Regarding the letters, we must not forget that we are all fruits of the time in which we live. The thoughts he expressed in his texts were very common at the time, like eugenics. Other writers who were celebrities at that time had similar ideas, but they did not survive the time. Therefore, painting Monteiro Lobato as a racist is a mistake.

After reading the text, the researcher I presented the following problem-question: Does the group agree with the position of the critic Ceccantini? Justify from the texts of the two literary works in focus and of their historical-cultural knowledge. For the PBL application, the researcher divided the class into five groups of five members. Each group nominated a president, one drafter, one rapporteur, member one and member two. The presidents forwarded and mediated the discussion of their respective groups. After each member set out their opinion, the group agreed on the answers. The editors wrote and the informers presented the group's responses.

Group 1: the author of the text was wrong about the fact that the children did not assimilate what is bad 
in the work, but they considered that such works should not go out of circulation. On the contrary, they should serve as examples not to be followed.

Group 2: the author of the text was wrong that the children did not assimilate what is bad in the work and the said works should be withdrawn from circulation.

Groups 3, 4 and 5: they did not agree with the critic that readers did not assimilate aspects of the works but agreed that they should continue to circulate. According to them, Monteiro Lobato was not a biased writer, but he was just a representative of a cruel historical period.

After the discussions and evaluations of the activity, the researcher 1 encouraged her students to apply the PBL methodology with students of basic education, using the same theme.

\subsection{Development of research in Elementary School}

The researcher II, who participated in the PBL we described in the previous session in, applied the methodology in the class where she teaches. Students are between the ages of 8 and 9. This time, she used the theme "Diversity and Afrodescendence to check how children experience Ethnicity relationships in the school context through literary reading. For this work, she used literatures listed below:

- "Invisible", by Tino Freitas and RenatoMoriconi. The book tells the story of a boy who had a super power: only he saw the invisible, represented by those people who are on the margins of society.

- $\quad$ "The boy Nito", by Sonia Rosa. Nito is a black boy, who had a mania cry for everything. Until his father tells him those men, do not cry. The boy begins to swallow the crying and sick. Parents call the doctor and the medicine is "uncrying". They all cry together and recognize that expressing emotions is part of every human being. All characters in this story are black kids.

- "Bruna and Moorhen Angola", by Almeida Gercilga. The author search through a legend enhance African roots. Bruna is a girl who feels alone and asks her grandmother to tell the story of Chicken Rag his grandmother had brought from Africa.

- $\quad$ "Beautiful girl's ribbon", by Ana Maria Machado.The book tells the story of a little black girl who had a ribbon in her hair; a bunny finds its beautiful color and want to be pretinho. The girl invents a story to her mother explains that she was black because of their ancestors. Rabbit decides to marry a bunny nightshade and then have little black puppies. Born puppies of all colors.

- $\quad$ "Tom", anonymous history. It is the story of a black boy who passes in front of a store and read the following announcement: "SOAP Miraculous! TURNS THINGS BLACK IN WHITE! ARTICLE DAY R \$ 7.00. "The boy shopping, go home and spend all the soap in an attempt to turn white. Failing to get all disappointed, comes the mother and it explains that God created all the different people because you like diversity. The boy ends up happy and accepts his color.

- $\quad$ "Prince Ranieri", by Nana Toledo. The book tells the story of a white boy prince, but very unhappy for not having the father's attention. So just isolated, without friends, as do many bad things to children. Until these revolting and resolve treat it the same way. The father realizes that his son needs him and changes his attitude toward it. In this book all, the characters are white.

- $\quad$ "The king's friend", by Ruth Rocha. The book tells the story of two children: Yoyo, farmer's son and Matthias, son of the farm slaves. The two are friends, but Yoyo was always right because he was the son of the boss. At the end, Matias becomes a king and Yoyo becomes the king's friend.

- "Princess Arabella, spoiled only her", by Mylo Freeman. The book tells the story of a very spoiled black princess who had everything. As a birthday gift, she asked for an elephant. The king and queen did the will of the girl. However, the elephant cried so much that the princess took him back to the forest. The elephant had a puppy who also wanted a gift princess. The princess becomes the elephant gift.

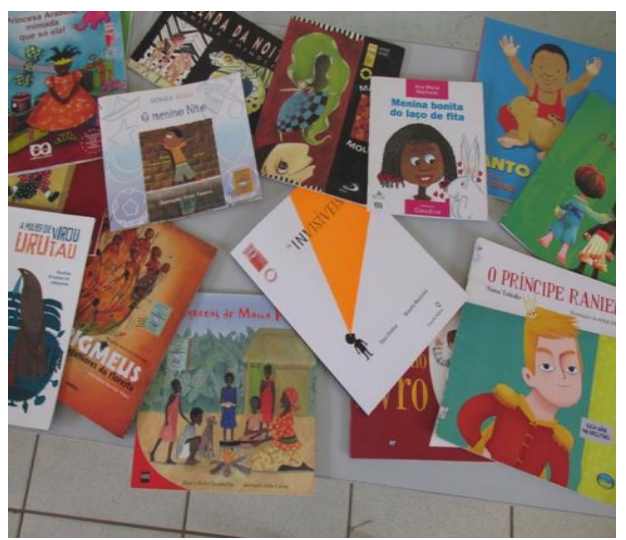

Figure 1. Children's storybooks suggested by the teacher 
The development of PBL occurred in the following stages:

Step one: the teacher organized the working in five groups, with five members. They chose their names and functions, namely: president, editor, rapporteur, and member one and member two.

Step two: the teacher introduced the subject in order to probe the students, to see what they knew, thought and how they experienced this cultural diversity, in school every day.

Step three: the teacher distributed books on children's literature, addressing themes about cultural and other diversity, in order to understand, through children's literature, the level of knowledge of children as well as their way of thinking about relationships between them.

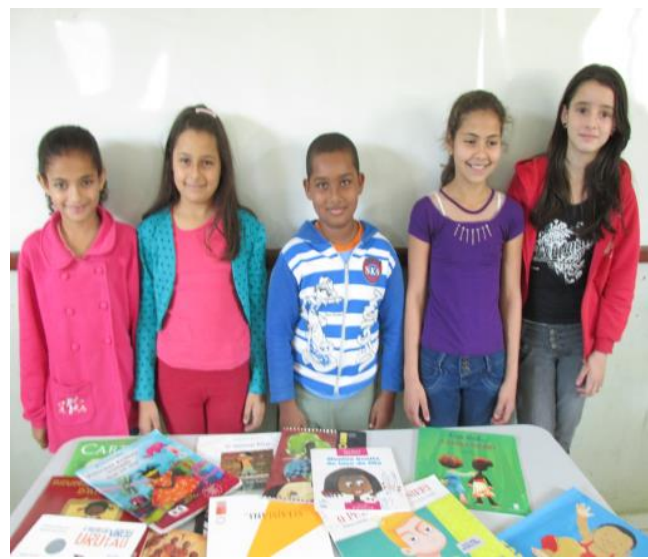

Figure 2. Group 1 and the books for reading

Step four: Based on the reading of the books, the students answered a group questionnaire.

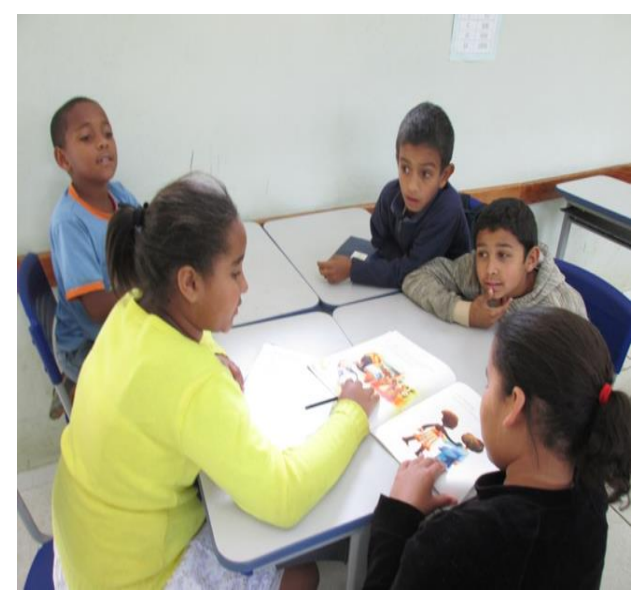

Figure 3. Participants reviewing the storybook

Next day, students answered an individual questionnaire.

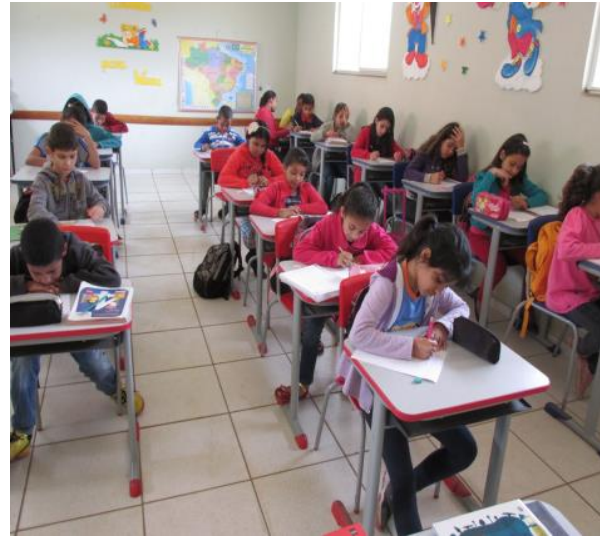

Figure 4. Participants answering individual questionnaire

Step five: Presentation: After presenting their individual responses and comparing them with the group's responses, the rapporteur from each group presented the results for the class. After the presentation, there was a small debate about the results. They are summarized in the table below.

Table 1. Results of groups responses

\begin{tabular}{|c|c|c|c|c|}
\hline GROUP & $\begin{array}{l}\text { SELECTED } \\
\text { STORYBOOK }\end{array}$ & $\begin{array}{l}\text { Character } \\
\text { representing } \\
\text { the group and } \\
\text { its } \\
\text { characteristics }\end{array}$ & $\begin{array}{l}\text { Point of } \\
\text { prominence of } \\
\text { the story }\end{array}$ & $\begin{array}{l}\text { Issues related } \\
\text { to diversity }\end{array}$ \\
\hline G1 & $\begin{array}{l}\text { The King's } \\
\text { Friend }\end{array}$ & $\begin{array}{l}\text { Matias: Black, } \\
\text { slave, African, } \\
\text { intelligent and } \\
\text { friendly }\end{array}$ & $\begin{array}{l}\text { A slave boy to } \\
\text { become king }\end{array}$ & $\begin{array}{l}\text { Friendship } \\
\text { between } \\
\text { people of } \\
\text { different skin } \\
\text { colors }\end{array}$ \\
\hline G2 & $\begin{array}{l}\text { The King's } \\
\text { Friend }\end{array}$ & $\begin{array}{l}\text { Matias: Black, } \\
\text { slave, African, } \\
\text { intelligent and } \\
\text { friendly }\end{array}$ & $\begin{array}{l}\text { The desire to } \\
\text { become king }\end{array}$ & $\begin{array}{l}\text { The white boy } \\
\text { was always } \\
\text { right }\end{array}$ \\
\hline G3 & The boy Nito & $\begin{array}{l}\text { Nito: Crying } \\
\text { baby boy }\end{array}$ & $\begin{array}{l}\text { The fact that he } \\
\text { has swallowed } \\
\text { the cry }\end{array}$ & The boy crying \\
\hline G4 & $\begin{array}{l}\text { Princess } \\
\text { Arabela, } \\
\text { spoiled that } \\
\text { only her }\end{array}$ & $\begin{array}{l}\text { Arabela: } \\
\text { beautiful and } \\
\text { happy }\end{array}$ & $\begin{array}{l}\text { The girl wanted } \\
\text { a gift elephant }\end{array}$ & $\begin{array}{l}\text { The main } \\
\text { character is a } \\
\text { black and } \\
\text { cheerful girl }\end{array}$ \\
\hline G5 & $\begin{array}{l}\text { Beautiful girl of } \\
\text { ribbon tie }\end{array}$ & $\begin{array}{l}\text { Girl: Black, } \\
\text { friendly, } \\
\text { determined, } \\
\text { good and } \\
\text { beautiful }\end{array}$ & $\begin{array}{l}\text { The rabbit and } \\
\text { its puppies }\end{array}$ & $\begin{array}{l}\text { The character } \\
\text { is a beautiful } \\
\text { black girl }\end{array}$ \\
\hline
\end{tabular}

Step 6: In the evaluation, the presidents took into account the commitment of each participant, according to their role, as well as the ability to work as a team. Then they did their self-assessment. 


\subsection{Considerations about results}

From observations of project development and student responses, we can state some findings. First, the application of the PBL with this group of students showed that this methodology not only entails changes in the teaching-learning process as it also poses challenges and different roles for the students as well as for the teacher. When compared to those associated with conventional education, since the learning takes place in an environment of support and collaboration.

The participants analyze the literary texts and find in it real world problems, in this case related to prejudice and racial discrimination. It was possible to perceive the change of attitude of the teacher who, instead of presenting ready ideas, delegated the students the responsibility to construct their own concepts, to delineate questions, to formulate problems, explore alternatives and take positions on the subject. Also, by exposing the results of their work in school and the community, to increase the motivation of students to do similar work, always broadening the social scope of literature.

However, some problems can be found, since it is a new methodology and different from the teaching methods to which students and teachers are used to.

Among the difficulties observed, we can mention groups with few cooperation among the members, more developed students intellectually and with greater verbal expression can constrain those more timid and with less potential. Besides, since the completely learning process occurs in groups, it is difficult for the teacher to evaluate the student's individual performance.

Another factor was not properly explored in this work was the interdisciplinary nature of this approach. It could be more interesting and complete if other disciplines were involved in the same project, as Sciences to explain the miscegenation of races and History, to deepen the socio-political aspect of this diversity in Brazil.

However, it cannot be denied that this active methodology allows putting into practice the knowledge acquired in the classroom, once it proposes challenges to the students. In this way, they develop leadership skills, teamwork and problem solving and are instigated to apply the acquired knowledge in practice situations.

\section{Conclusion}

The application of PBL provided students with a change of position in the classroom: from spectators of teacher explanation to agent of learning. The problems guide the students to take positions in the search for solutions. This method contributed to the crossing of a passive student, individualist to an active student, committed to social practices that benefit the other. The students were able to work directly and concretely with a theme that is part of their reality.

Although we are still in the field of experimentation, it was possible to bring academic research closer to the experience in the classroom. Such spaces of knowledge used to move in parallel, but little by little researchers and teachers begin to find convergent points and thus contribute mutually to the learning process.

These referrals were not in the habit of writing scientific works and, based on the socialization of knowledge and respect for diversity, made possible by the PBL and Projects mainly these two, many lectures were elaborated and presented by them, accompanied by the researchers, in different municipalities.

In spite of the challenges of new methods in pedagogical practice, the success of this experience has motivated us to elaborate a workshop in order to share with other educators and contribute to the debate about an education that provides the students the place of subject of their own learning.

\section{References}

[1] R. Pompéia (1996). O Ateneu. 16ª ed., São Paulo: Ática.

[2] O. de Andrade. (1976) 'O manifesto antropófago' in G. B. Teles. Vanguarda europeia e modernismo brasileiro: apresentação e crítica dos principais manifestos vanguardistas. $3^{\text {a }}$ ed. Petrópolis: Vozes; Brasília: INL.

[3] J. M. de Carvalho. (1988), Teatro de sombras. São Paulo/Rio de Janeiro, Vértice/Iuperj.

[4] BRASIL. Parecer CNE/CES $n^{o} 1.302$ de 06 de dezembro de 2001.

[5] J. G. Sacristán and A. I. P. Gómez (2000). Compreender e transformar o ensino. 4. Ed. Porto Alegre: AR-TMED.

[6] D. A. Shön (2000). Educando o profissional reflexivo: um novo design para o ensino aprendizagem. Porto alegre: Artes Médicas Sul.

[7] E. Morin (2000). Os sete saberes necessários à educação do futuro. tradução de Catarina Eleonora F. da Silva e Jeanne Sawaya ; revisão técnica de Edgard de Assis Carvalho. - 2. ed. - São Paulo: Cortez; Brasília, DF: UNESCO.

[8] É. Chalier (2001). Formar professores profissionais para uma formação contínua articulada à 
prática. In: PAQUAY, Léopold; PERRENOUD, Philippe, et al (Org.). Formando professores profissionais: Quais estratégias? Quais competências? 2. ed. Porto Alegre, Artmed, p. 85102.

[9] T. R. Hannas (2017). (Org.). Metodologias ativas de ensino: manual de aplicação. Belo Horizonte: $3 \mathrm{i}$ Editora.

[10] E. Morin (2003). A cabeça bem-feita: repensar a reforma e o pensamento. 8. Ed. Tradução Eloá Jacobina. Rio de Janeiro: Bertrand Brasil.

[11] J. Elliot (199). Action research for educational change. Philadelphia: Open University Press.

[12] N. Goulart (2017). 'Censurar Monteiro Lobato é analfabetismo histórico', www://veja.abril.com.br educacao/censurar-monteiro-lobato-e-analfabetismohistorico.

[13] E. Morin (1999). A cabeça bem-feita: repensar a reforma e o pensamento. 8. Ed. Tradução Eloá Jacobina. Rio de Janeiro: Bertrand Brasil, 1999. 